\title{
PENGARUH GAWAI TERHADAP PEMEROLEHAN BAHASA ANAK USIA 4 TAHUN: KAJIAN ASPEK SINTAKSIS
}

\author{
Fathur Rahmi Affauzani ${ }^{1)}$ \\ Fakultas Tarbiyah dan Ilmu Keguruan, Universitas Islam Negeri Syarif Hidayatullah Jakarta \\ email: affauzani.rahmi17@mhs.uinjkt.ac.id
}

\begin{abstract}
Abstrak
Keberadaan gawai pada era modern telah menjadi kebutuhan primer sejalan dengan perkembangan teknologi. Kehadirannya selain berdampak pada kehidupan masyarakat (orang dewasa) juga dapat memengaruhi proses pemerolehan bahasa bagi anak yang bermain gawai. Penelitian ini bertujuan untuk memaparkan pemerolehan bahasa anak usia 4 tahun yang dipengaruhi oleh gawai melalui telaah bidang sintaksis, yakni berupa kalimat berita, kalimat tanya, dan kalimat suruh. Sumber data berasal dari rekaman video dan audio anak yang menjadi subjek penelitian, sedangkan data berupa transkrip dari rekaman video dan audio. Teknik pengumpulan data dilakukan dengan tiga cara, yaitu (1) merekam kegiatan anak yang dijadikan bahan penelitian, (2) mentranskrip pembicaraan, dan (3) menganalisis data sesuai dengan topik penelitian. Penelitian ini menggunakan metode deskriptif-kualitatif dengan mendeskripsikan informasi yang didapat dari data yang telah dikumpulkan. Hasil penelitian yang diperoleh di antaranya, pertama gawai sangat mempengaruhi pemerolehan sintaksis bahasa anak usia 4 tahun terhadap produksi kalimat berita, kedua gawai tidak terlalu berpengaruh terhadap pemerolehan bahasa anak usia 4 tahun dalam produksi kalimat tanya, dan ketiga gawai tidak berpengaruh terhadap pemerolehan sintaksis bahasa anak usia 4 tahun dalam produksi kalimat perintah.
\end{abstract}

Kata Kunci: gawai, pemerolehan bahasa, sintaksis.

\section{Abstract}

The existence of a gadgets in the modern era has become a primary need in line with technological development. Its presence not only impacting the life of the community (adults) but also affecting the process of language acquisition for children who use gadgets. Through syntax field study, this paper aims to explain about the language acquisition of 4-year-old child which got affected by the gadgets, in the form of declarative, interrogative, and imperative. The source are from the video and audio recordings. Data collection techniques completed in three steps, (1) record the cild's activities which later will be use as the material of the research, (2) transcribe the conversation, and (3) nalyse the data that is relevant to the research topic. This paper used a qualitative descriptive method by describing the information obtained from the data collected. Further, the pape has come to several results. First, gadgets greatly influenced the acquisition of syntax whitin a 4-year-old child when producing declarative (affirmative). Second, gadgets do not affect the language acquisition of 4-year-old in the production of interrogative sentences in a significant manner. Last but not least, gadgets have no effect in the language acquisition of syntax for the 4-year-old child when producing imperative sentences.

Keywords: gadgets, language acquisition, syntax.

\section{PENDAhUluaN}

Nuryani \& Putra (2013: 90) mengungkapkan, "pemerolehan bahasa mengacu pada penguasaan bahasa pertama secara alami, tidak sadar, tidak terencana, dan tidak bertendensi memperoleh pengetahuan mengenai sistem kaidah bahasa pertama tetapi penguasaan bertendensi untuk berkomunikasi. " Artinya pemerolehan bahasa yang dimaksud berhubungan dengan penguasaan bahasa pertama anak dalam berkomunikasi. Selanjutnya, Tarigan (1986: 243) mengemukakan bahwa "pemerolehan bahasa atau language acquisition adalah suatu proses yang dipergunakan oleh kanak-kanak untuk menyesuaikan serangkaian hipotesis yang makin bertambah rumit, ataupun teori-teori yang masih terpendam atau tersembunyi yang mungkin sekali terjadi, dengan ucapan-ucapan orang tuanya sampai dia memilih, berdasarkan suatu ukuran atau takaran penilaian, tata bahasa yang paling baik serta yang paling sederhana dari bahasa tersebut." Ia juga berpendapat bahwa pemerolehan bahasa ditentukan oleh interaksi aspek-aspek kematangan biologis, kognitif, dan sosial (Tarigan, 2011: 5). Dengan demikian, dapat 
disimpulkan bahwa pemerolehan bahasa adalah penguasaan bahasa seorang anak secara alami yang didasarkan pada asumsi yang telah didengar dari lingkungan keluarganya sehingga ia dapat menyimpulkan sendiri apa maksud dari bahasa tersebut.

Seperti yang dikatakan oleh Simanjuntak (2009: 104) bahwa "pemerolehan bahasa adalah sebuah proses yang terjadi di dalam otak seorang anak ketika ia sedang memperoleh bahasa ibunya." Dengan demikian, dapat diketahui bahwa proses pemerolehan bahasa dilakukan di dalam otak anak secara bertahap untuk memperoleh pengetahuan yang lebih kompleks mengenai bahasa pertama atau bahasa ibunya.

Pada usia kanak-kanak pemerolehan bahasa yang didapat oleh anak baru berupa tiruan bunyi yang didengar dari orang dewasa, tataran kata, frase, bahkan mungkin berupa kalimat tetapi belum memiliki struktur yang sempurna. Setelah anak berusia lebih dari dua tahun, misalnya usia empat tahun, ia mulai dapat mengungkapkan kalimat-kalimat yang telah memiliki arti, ia juga sudah dapat bercerita, dan anak menjadi lebih emosional. Terlebih lagi jika anak tersebut bergaul di lingkungan yang kerap menggunakan gawai. Lingkungan yang sering menggunakan gawai dapat berpengaruh terhadap pemerolehan bahasa anak. Melalui gawai tersebut ia membuka sebuah aplikasi, salah satunya aplikasi yang kita kenal adalah Youtube. Dari aplikasi tersebut, anak-anak menonton, menyimak, serta menirukan suara atau bunyibunyi yang didengarnya dari tontonan tersebut. Akibatnya, pemerolehan bahasanya semakin meluas, dan lebih menyerupai omongan orang dewasa. Sejalan dengan pemaparan tersebut, perlu kita ketahui terlebih dahulu mengenai gawai. Kemkoninfo (2015) mengatakan bahwa "gawai ialah salah satu perkembangan teknologi yang pemakaiannya rata-rata dipakai oleh semua usia, termasuk di dalamnya anakanak usia di bawah 5 tahun."

Berdasarkan definisi tersebut, dapat diketahui bahwa pemakaian gawai bukan hanya digunakan oleh orang dewasa saja, melainkan anak-anak yang berusia di bawah 5 tahun. Perkembangan teknologi dunia yang kian pesat, membuat keberadaan gawai menjadi mudah untuk diakses, seperti melalui telepon seluler, tablet, bahkan laptop. Banyaknya aplikasi yang terdapat di dalam gawai, menyebabkan anak-anak menjadi terusmenerus bermain gawai. Misalnya saja, aplikasi Youtube yang dapat diunduh dengan mudah melalui gawai. Lewat aplikasi tersebut, banyak anak-anak yang lebih sering bermain gawai daripada bermain di lingkungan luar rumah bersama dengan teman sebayanya. Anak-anak lebih mementingkan menonton video-video Youtube yang menarik dan bervariasi. Tak jarang, mereka meniru ucapanucapan dari tontonan Youtube. Seperti "Hai guys, kembali lagi bersama saya ...," dan sebagainya. Ketika gawai sudah menjadi candu bagi anak-anak, sulit bagi orang tua untuk mengontrol waktu bermain anak menggunakan gawai tersebut. Akibatnya anak menjadi lebih emosional dari biasanya, bahkan ia sering bersuara keras (teriak) pada orang di sekitarnya yang mengganggunya bermain gawai tersebut. Terlebih lagi, jika durasi anak bermain gawai telah melewati batas, maka ia tak segan-segan untuk menangis hingga merajuk.

Melalui keberadaan gawai tersebut, pemerolehan bahasa anak dapat ditinjau melalui telaah bidang sintaksis. Seperti bagaimana kalimat yang dihasilkannya, misalnya kalimat berita (pernyataan), kalimat tanya, dan kalimat suruh (perintah). Disebutkan oleh Ramlan (2005: 18) bahwa "sintaksis merupakan cabang dari ilmu bahasa yang membicarakan tentang seluk beluk wacana, kalimat, klausa, dan frase." Bagi Chaer (2014: 206) "sintaksis adalah ilmu yang membahas tentang kata dalam hubungannya dengan kata lain, atau unsur-unsur lain sebagai suatu satuan ujaran. Sintaksis menempatkan kata-kata secara bersamaan menjadi kelompok kata atau kalimat." Dengan kata lain, sintaksis merupakan studi gramatikal struktur antarkata. 
Lebih dalam lagi, fungsi kalimat dalam sintaksis dapat dihubungkan dengan situasi yang digolongkan ke dalam (1) kalimat berita, merujuk kepada sebuah fungsi untuk memberitahu informasi dan mengharapkan respon perhatian dari orang lain, (2) kalimat tanya, mengacu kepada fungsi sebuah kalimat untuk menanyakan sesuatu, dan (3) kalimat suruh, melihat lebih lanjut fungsi kalimat yang mengharapkan sebuah tindakan dari orang lain (Ramlan, 2005: 26-39).

Darjdowidjojo (2008: 246) menyebutkan bahwa "dalam bidang sintaksis, anak mulai berbahasa dengan mengucapkan satu kata (atau bagian kata) yang menurut anak tersebut merupakan suatu kalimat penuh, karena ia belum mengucapkan lebih dari satu kata. Kalimat diucapkan untuk memberikan informasi baru kepada pendengarnya." Dengan demikian, maka peneliti untuk menganilisi data menggunakan teori hubungan tata bahasa dan informasi situasi. Teori tersebut merujuk kepada pemakaian gabungan kata-kata oleh anak-anak dalam situasi yang berlainan. Artinya pemakaian gabungan kata tersebut disesuaikan oleh konteks yang berlaku.

\section{KAJIAN LITERATUR}

Penelitian yang dilakukan oleh Impuni pada tahun 2012 dengan judul "Pemerolehan Sintaksis Anak Usia Lima Tahun Melalui Penceritaan Kembali Dongeng Nusantara" membahas mengenai pemerolehan sintaksis dengan media menceritakan kembali dongeng yang didengar dapat diterapkan sesuai dengan standar kompetensi yang ada. Bahasan pokok penelitian tersebut sama dengan penelitian yang penulis lakukan, yakni mengenai pemerolehan sintaksis anak. Tetapi penelitian Impuni anak yang dijadikan subjek penelitian berusia 5 tahun, sedangkan penulis meneliti anak yang berusia 4 tahun. Selanjutnya, Impuni meneliti dengan penceritaan dongeng nusantara yang dilakukan oleh anak tersebut. Sedangkan penulis meneliti pengaruh gawai terhadap pemerolehan sintaksis anak usia 4 tahun.
Selanjutnya Ismarini Hutabarat pada tahun 2018 melakukan penelitian dengan judul "Pemerolehan Sintaksis Bahasa Indonesia pada Anak Usia Dua Tahun dan Tiga Tahun di Padang Bulan". Penelitian tersebut membahas mengenai pemerolehan bahasa Indonesia anak usia dua dan tiga tahun pada tingkat kalimat berdasarkan modus, kemudian perbedaan pada pemerolehan bahasa Indonesia anak usia dua tahun dan tiga tahun pada tingkat kalimat berdasarkan modus, dan melihat faktor-faktor yang mempengaruhi pemerolehan sintaksis bahasa anak usia dua dan tiga tahun. Penelitian tersebut memiliki persamaan dengan penelitian ini, yakni sama-sama membahas mengenai pemerolehan sintaksis bahasa anak. Namun, penelitian ini membahas mengenai pemerolehan bahasa anak usia 4 tahun, sedangkan penelitian Hutabarat mengenai anak usia dua dan tiga tahun. Pokok bahasan dalam penelitian ini adalah pengaruh gawai, sedangkan penelitian Hutabarat hanya meneliti pemerolehan sintaksi dilihat dari faktor-faktor yang mempengaruhinya.

\section{METODE PENELITIAN}

Penelitian ini merupakan penelitian deskriptif kualitatif. Sudaryanto (1993: 62) menyebutkan bahwa "penelitian deskriptif adalah penelitian yang dilakukan hanya berdasarkan fakta dan fenomena yang memang secara empiris hidup pada penutur-penuturnya, sehingga yang dihasilkan atau dicatat berupa perian bahasa yang bisa dikatakan sifatnya seperti potret. Sedangkan penelitian kualitatif menurut Mahsun (2007: 257) ialah "penelitian yang berfokus pada penunjukkan makna, deskripsi, penjernihan, dan penempatan data pada konteksnya masing-masing dan sering kali melukiskannya dalam bentuk kata-kata daripada angka-angka."

Sumber data penelitian berasal dari rekaman video serta audio yang berkaitan dengan kegiatan anak yang menjadi subjek penelitian tersebut sejak 1 Oktober 2019 hingga 8 Desember 2019, namun pengambilan rekaman tidak dilakukan setiap hari. 
Selanjutnya data dalam penelitian ini berupa transkrip dari rekaman video dan audio tersebut. Transkrip tersebut hanya memuat struktur kata serta kalimat yang akan dianalisis. Teknik pengumpulan dalam penelitian dilakukan melalui tiga cara, yakni (1) merekam kegiatan anak baik di lingkungan maupun sekolah, (2) mentranskrip ujaran anak tersebut sebagai data penelitian, menganalisis data pemerolehan bahasa. Anak yang dijadikan sebagai subjek penelitian berusia 4 tahun, dan sudah bersekolah di PAUD Kemuning. Penggunaan gawai pada anak tersebut biasanya berdurasi sekitar 2-3 jam tetapi dalam sehari dapat beberapa kali anak tersebut menggunakan gawai. Gawai tersebut digunakannya untuk menonton video dari aplikasi Youtube, tontonannya berupa kartun anak-anak, sinetron Kun Anta, dan lainlain.

\section{HASIL DAN PEMBAHASAN}

Anak yang menjadi subjek dalam penelitian ini bernama Anisa Faradilla, berusia 4 tahun. Anisa merupakan anak terakhir dari tiga bersaudara. Anisa telah bersekolah di PAUD Kemuning mulai dari bulan Juli 2019. Anisa lahir di Jakarta, 3 Maret 2019. Dari data penelitian yang telah ditranskrip, maka peneliti mencoba menjabarkan pengaruh gawai terhadap bahasa anak melalui telaah bidang sintaksis, yakni berupa pemerolehan kalimat berita, kalimat tanya, dan kalimat suruh. Terdapat 20 ujaran yang tergolong ke dalam kalimat berita, kemudian 5 kalimat pertanyaan, serta 2 kalimat perintah. Berikut ini adalah penjabarannya.

\section{a. Kalimat Berita}

Kalimat berita merupakan kalimat yang bertujuan untuk memberitahu informasi kepada seseorang dan mengharapkan sebuah tanggapan berupa perhatian dari seseorang yang diajak berbicara.

1) Peneliti: Hobi dede apa?

Anisa: Hobi dede bertemen.

Kalimat tersebut merupakan sebuah pernyataan mengenai kegemaran Anisa, ketika peneliti menanyakan sesuatu yang menjadi hobinya. Kemudian anak tersebut memberitahu bahwa hobi yang digemarinya adalah berteman. Meskipun kalimat tersebut memiliki makna yang rancu, namun anak tersebut menjawabnya dengan lugas.

2) Peneliti: Itu apa sih, dek?

Anisa: Namanya es krim soda.

Ketika peneliti menanyakan sesuatu yang sedang dimainkan olehnya, ia menjawab dengan sebuah pernyataan bahwa itu adalah es krim soda.

3) Anisa: Wah, angka tiganya gede banget.

Kalimat tersebut merupakan kalimat pernyataan yang mengandung makna bahwa angka 3 yang dilihatnya besar, lebih besar dari biasanya.

4) Anisa: Halo, guys! Hai, aku lagi nonton $h p$ papa aku. Enggak ketahuan

Kalimat tersebut berisi pernyataan ketika ia sedang memainkan telepon seluler milik Papa nya, kemudian dalam kalimat tersebut ia perjelas kalau Papa nya tidak tahu smartphone nya sedang dimainkan. Dalam kalimat ini, terlihat bahasa yang digunakannya yakni ' $\mathrm{Hai}$, guys' seperti yang banyak dituturkan oleh para Youtuber (orang yang aktif mengunggah video di Youtube dengan berbagai konten), merupakan pengaruh dari kegiatannya bermain gawai terhadap bahasa yang diperolehnya.

5) Anisa: Hai, aku lagi beresin pasir, karena dede mau tidur.

Kalimat tersebut berupa kalimat berita yang berisi pernyataan kegiatan yang dilakukannya yakni membereskan pasir yang sedang dimainkannya karena ia mau segera tidur. Penggunaan kata 'Hai' juga terindikasi masuk ke dalam pengaruh penggunaan gawai, yang secara lebih spesifik terdapat pada aplikasi Youtube.

6) Anisa: (menuangkan pasir ke ember) Kebanyakan, guys.

Kalimat tersebut berisi pernyataan tentang pasir yang akan dituangkan ke ember terlalu banyak ketika diambil. Anak tersebut menggunakan sapaan 'guys' yang sering didengarnya ketika menonton Youtube. 
7) Anisa: Tadi kita memotong buah apel. (menunjukkan apel mainan) Ini, guys!

Kalimat di atas berisi tentang pernyataan Anisa bahwa ia telah melakukan suatu pekerjaan atau perbuatan, yakni memotong buah apel mainan. Ia menunjukkan kepada peneliti dengan menggunakan kata sapaan 'guys'.

8) Anisa: Temen-temen lupa mulu deh dengan buah apel.

Kalimat tersebut dituturkan oleh Anisa ketika orang yang menjadi kawan mainnya sering lupa dengan buah apel. Kata sapaan 'teman-teman' pada kalimat tersebut merujuk kepada seseorang yang dianggap sedang bermain dengannya, karena kata tersebut sering ditampilkan di Youtube ketika sedang menyapa penontonnya yakni dengan menggunakan kata 'teman-teman', dan kata tersebut kerap kali digunakan oleh Anisa untuk menyapa orang yang ada di hadapannya ketika ia sedang bermain.

9) Anisa: Ternyata mata itu ilang, dan muncul di sini.

Kalimat di atas menyatakan bahwa ada salah satu mata ikan mainannya yang hilang, dan ternyata ditemukannya di suatu tempat yang letaknya tak berjauhan dengannya.

10) Anisa: Yah, salah, guys. Kita hapus ya, guys. Ini namanya penghapus.

Kalimat tersebut dituturkan oleh Anisa ketika ia sedang menggambar sesuatu tetapi gambar yang dibuatnya ternyata salah, kemudian dia akan menghapusnya dengan menggunakan penghapus. Kalimat yang berisi pernyataan atau berita tersebut mengandung sebuah kata yang terdapat dalam tanyangan Youtube, yakni kata 'guys' seperti yang telah sering disebutkan sebelumnya.

11) Anisa: Ini namanya lifebuoy (menunjukkan botol sabun merk lifebuoy). Wangi banget.

Kalimat pernyataan tersebut mengandung arti bahwa botol sabun yang sedang dipegangnya bermerk Lifebuoy, anak tersebut mengetahui merk tersebut meskipun ia belum bisa membaca, karena sabun yang sering dipakainya bermerk Lifebuoy, dan ia menegaskan kalau sabun tersebut beraroma sangat wangi.

12) Anisa: $\mathrm{Bu}$, dede bisa nulis angka ini.

Kalimat tersebut berisi pernyataan yang dituturkan oleh Anisa kepada Ibu, bahwa ia dapat menulis sebuah angka tertentu.

13) Anisa: Aku bisa angka lima.

Kalimat tersebut berisi pernyataan bahwa anak tersebut sudah dapat menulis angka lima.

14) Anisa: Aku mau mancing.

Kalimat tersebut berisi pernyataan mengenai kegiatan yang ingin dilakukannya, yakni memancing. Kata 'memancing' di sini bukan merujuk kepada kegiatan memancing ikan di danau atau sungai, melainkan permainan memancing dengan menggunakan alat pancingan mainan.

15) Anisa: Ada bak mandi, nih.

Kalimat tersebut menginformasikan mengenai sesuatu yang ia lihat, yakni bak mandi. Bak mandi tersebut merupakan bak mandi mainan yang kecil yang sering dimainkan olehnya.

16) Anisa: Ada yang dateng, $\mathrm{Bu}$.

Ibu: Enggak ada udah. Ini udah malem, udah jam delapan.

Kalimat tersebut berisi berita yang disampaikan oleh Anisa, yakni ada seseorang yang datang ke rumah untuk mengaji, namun Ibu menjawab bahwa tidak ada lagi orang yang datang karena waktu sudah menunjukkan pukul delapan malam, yang artinya tidak ada lagi orang yang datang untuk mengaji.

17) Peneliti: Ini siapa yang gambar?

Anisa: Dede.

Peneliti: Terus kenapa dihapus?

Anisa: Biar enggak dimarahin kakak.

Kalimat tersebut terjadi ketika peneliti dan Anisa sedang menggambar bersama-sama, kemudian peneliti bertanya mengenai siapa yang menggambar, kemudian ia mengatakan bahwa gambar tersebut adalah hasil karyanya. Namun ketika penulis bertanya mengapa gambar tersebut dihapus, ia menyatakan gambar tersebut dihapus agar tidak dimarahi oleh kakaknya. 
18) Anisa: Ini namanya $E X O$.

Peneliti: Apa itu EXO?

Anisa: Ini EXO, nanti EXO taro sini, ondelondel taro sini.

Kalimat di atas memiliki konteks ketika peneliti menanyatakan tentang sesuatu yang dipajang di kamarnya, kemudian ia menyatakan bahwa sesuatu tersebut bernama EXO (pigura yang menampilkan gambar boyband asal Korea Selatan, EXO). Anak tersebut kemudian memberi pernyataan tentang tata letak pigura yang akan di pajang di kamarnya.

19) Peneliti: Nanti kamu diomelin kakak, kamar kakak berantakan banyak bekas penghapus.

Anisa: Enggak papa, nanti dia beresin sendiri.

Kalimat tersebut berisi pernyataan bahwa tidak apa-apa kamar Kakak nya berantakan, karena nanti yang akan membereskan kamar tersebut adalah Kakaknya. Saat itu peneliti berkata bahwa jika kamar tersebut berantakan karena banyak bekas pengahapus berteberan di lantai, apabila tidak dibersihkan akan dimarahi oleh Kakaknya.

20) Peneliti: Ini gambar apa?

Anisa: Gambar ikan lumba-lumba.

Kalimat tersebut menggambarkan sebuah pernyataan yang dinyatakan oleh Anisa, yakni ketika peneliti menanyakan tentang sebuah gambar, Anisa menjawab bahwa gambar tersebut adalah gambar ikan lumba-lumba.

Melalui data tersebut dapat diketahui bahwa gawai mempengaruhi pemerolehan bahasa anak, ditunjukkan melalui penggunaan beberapa kata yang sering diucapkan oleh Youtuber, di antaranya, kata (1) Hai, guys! atau Halo, guys!, (2) kata sapaan guys!, dan (3) kata sapaan 'teman-teman'. Dengan demikian, dapat diketahui bahwa pengaruh gawai terhadap pemerolehan bahasa anak usia 4 tahun sangat berpengaruh terhadap produksi kalimat berita atau pernyataan. Hal tersebut ditunjukkan dengan adanya 20 kalimat berita yang dituturkan oleh Anisa.

\section{b) Kalimat Tanya}

Kalimat tanya merupakan sebuah kalimat yang berfungsi untuk menanyakan sesuatu.

(1) Anisa: Itu buaya ya?

Kalimat tersebut merupakan sebuah kalimat yang mempertanyakan apakah hewan tersebut buaya atau bukan. Kalimat tersebut dapat dilengkapi dengan struktur kalimat tanya berupa penambahan kata Apakah atau Kah. Menjadi, "Apakah itu buaya?" atau "Buayakah itu?".

(2) Anisa: Gambar apa itu?

Kalimat tersebut merupakan pertanyaan yang diajukan oleh Anisa kepada peneliti mengenai sebuah gambar. Ia menanyakan gambar apa yang dilihatnya. Dalam kalimat tersebut terdapat kata tanya berupa kata "apa". Kalimat tersebut dapat diubah strukturnya menjadi "Itu gambar apa?" Kalimat tersebut menanyakan tentang identitas sebuah gambar.

(3) Anisa: Tadi kita potong apa, hayo? Potong apa, hayo? Siapa yang tahu, guys?

Kalimat tersebut membicarakan tentang sesuatu yang dipotong. Anisa mengajukan sebuah pertanyaan kepada peneliti mengenai benda apa yang telah dipotongnya. Kalimat tersebut mengandung sebuah kata tanya berupa kata apa dan siapa. Anisa juga menggunakan kalimat sapaan berupa kata guys. Kata tanya apa merujuk kepada pertanyaan mengenai sebuah benda yang telah dipotong, sedangkan kata tanya siapa merujuk kepada seseorang yang mengetahui atau tidak benda yang telah dipotong. Kalimat tersebut dapat diubah strukturnya menjadi "Apa yang tadi kita potong?".

(4) Anisa: Ah, kenapa disobekin semua?

Kalimat tersebut menanyakan mengapa sesuatu yang ia maksud telah disobek semua. Anisa menggunakan kata tanya kenapa untuk menanyakan sebab mengenai benda yang telah sobek.

(5) Anisa: Bunyi apa tuh?

Peneliti: Barongsai.

Kalimat tersebut berisi tentang sebuah pertanyaan mengenai bunyi yang didengar olehnya. Anisa menanyatakan bunyi apa yang didengarnya kepada peneliti, kemudian 
peneliti menjawab bahwa itu adalah bunyi barongsai. Kalimat tersebut dapat diubah strukturny menjadi "Itu bunyi apa?"

Dalam kalimat pertanyaan, Anisa hanya menggunakan satu kali kata sapaan yang terpengaruh dari tontonan Youtube yakni kata ' guys' yang terdapat pada kalimat ke tiga. Kata tanya hanya muncul dalam lima kalimat. Hal tersebut menunjukkan bahwa pengaruh gawai terhadap pemerolehan sintaksis bahasa anak usia 4 tahun dilihat dari tataran sintaksis yakni kalimat pertanyaan masih terbilang rendah. Artinya, anak tersebut jarang menggunakan kata-kata yang terpengaruh dari Youtube untuk digunakan dalam kalimat pertanyaan. Kata tanya yang muncul dalam kalimat pertanyaan yang diucapkan oleh Anisa berupa kata tanya apa, siapa, dan kenapa (mengapa), sedangkan kata tanya bagaimana, mana, bilamana, bila, kapan, dan berapa tidak diucapkan olehnya.

\section{c) Kalimat Suruh}

Kalimat suruh merupakan kalimat yang mengharapkan adanya suatu tindakan yang dilakukan.

(1) Anisa: Ayo kita pasang kakinya!

Kalimat tersebut merupakan kalimat suruh. Anisa mengucapkan kalimat tersebut untuk mengajak peneliti memasang kaki sebuah mainan. Kalimat suruh tersebut masuk ke dalam kalimat ajakan, yang mengharapkan tanggapan dari seseorang yang diajak bicara. Kalimat suruh tersebut dapat diubah strukturnya menjadi "Ayolah pasang kakinya!"

Dalam kalimat suruh peneliti tidak menemukan sebuah kata yang terindikasi ke dalam sebuah kata yang terpengaruh dari tontonan Youtube yang terdapat pada gawai anak tersebut. Kemudian, kalimat suruh hanya satu kali diucapkan oleh Anisa, hal tersebut menunjukkan bahwa pengaruh gawai terhadap pemerolehan sintaksis bahasa anak usia 4 tahun memiliki intensitas yang rendah.

\section{KESIMPULAN}

Berdasarkan pembahasan yang telah diutarakan, peneliti menarik simpulan bahwa pengaruh gawai terhadap pemerolehan bahasa anak usia 4 tahun mempengaruhi produksi kalimat berita, kalimat tanya, dan kalimat suruh (perintah). Dari 26 kalimat yang dituturkan oleh Anisa, sebagai subjek penelitian, terdapat 20 kalimat yang terindikasi sebagai kalimat berita (pernyataan), 5 kalimat tanya, dan 1 kalimat suruh (perintah). Dari hasil tersebut menunjukkan bahwa pengaruh gawai terhadap pemerolehan bahasa anak usia 4 tahun sangat berpengaruh terhadap produksi kalimat berita atau pernyataan.

Di dalam kalimat berita terdapat beberapa kata yang bersumber dari gawai, khususnya aplikasi Youtube yang mempengaruhi pemerolehan bahasa anak, ditunjukkan dengan seringnya pengucapan kata (1) Hai, guys! atau Halo, guys!, (2) kata sapaan guys!, dan (3) kata sapaan 'teman-teman'. Kemudian ditinjau dari kalimat pertanyaan, pengaruh gawai terhadap pemerolehan bahasa anak usia 4 tahun tidak terlalu terlihat begitu jelas, karena hanya terdapat 5 kalimat yang mengandung isi sebuah pertanyaan, namun di dalam kalimat pertanyaan tersebut terdapat satu kali kata sapaan yang digunakan oleh anak tersebut yang terpengaruh dari tontonan Youtube yakni kata 'guys'. Jika dilihat dari produksi kalimat suruh (perintah) pengaruh gawai terhadap pemerolehan sintaksis bahasa anak usia 4 tahun memiliki intensitas yang rendah.

\section{REFERENSI}

Chaer, A. 2014. Linguistik Umum. Jakarta: Rineka Cipta.

Dardjowidjojo, S. 2003. Psikolinguistik: Pengantar Pemahaman Bahasa Manusia. Jakarta: Yayasan Obor Indonesia.

Hutabarat, Ismatrini. 2018. Pemerolehan Sintaksis Bahasa Indonesia pada Anak Usia Dua Tahun dan Tiga Tahun di Padang Bulan. Jurnal Darma Agung, XXVI (1), 661-676.

Impuni. 2012. Pemerolehan Sintaksis Anak Usia Lima Tahun Melalui Penceritaan Kembali Dongeng Nusantara. Jurnal Penelitian Humaniora, 13 (1), 30-41. 
Kementerian Komunikasi dan Informatika Republik Indonesia. 2015. Indonesia Raksasa Teknologi Digital Asia. https://www.kominfo.go.id.

Mahsun. 2007. Metode Penelitian Bahasa. Jakarta: Raja Grafindo Persada.

Nuryani, \& Putra, D.A.K. 2013. Psikolinguistik. Tangerang Selatan: Mazhab Ciputat.

Ramlan, M. 2005. Ilmu Bahasa Indonesia: Sintaksis. Yogyakarta: C.V. Karyono.

Simanjuntak, M. 2006. Pengantar Neuropsikolinguistik, Menelusuri Bahasa, Pemerolehan Bahasa dan Hubungan Bahasa dengan Otak. Perpustakaan Nasional Republik Indonesia.

Sudaryanto. 1993. Metode dan Teknik Analisis Bahasa: Pengantar Penelitian Wahana Kebudayaan secara Linguistik. Yogyakarta: Duta Wacana University Press.

Tarigan, H.G. 1986. Psikolinguistik. Bandung: Penerbit Angkasa.

2011. Pengajaran Pemerolehan

Bahasa. Bandung: CV Angkasa 